\title{
FLORAL, RESIN-SECRETING TRICHOMES IN Maxillaria dichroma ROLFE (ORCHIDACEAE: MAXILLARIINAE)
}

\author{
Małgorzata Stpiczyńska ${ }^{1 *}$, Kevin L. Davies ${ }^{2}$ \\ ${ }^{1}$ Department of Botany, University of Life Sciences, Akademicka 15, 20-950 Lublin Warsaw University, Botanic Garden, \\ Al. Ujazdowskie 4, 00-478 Warszawa, Poland \\ *For correspondence. E-mail malgorzata.stpiczynska@up.lublin.pl \\ ${ }^{2}$ School of Earth and Ocean Sciences, Cardiff University, Main Building, \\ Park Place, Cardiff CF10 3AT, UK
}

Received: 8.09.2009

\section{Abstract}

Resin-secreting, sunken, glandular trichomes have been described from the vegetative organs of Maxillaria and certain related taxa. However, until now, these hairs have not been recorded for Maxillaria flowers, nor have they been examined at the ultrastructural level for any part of the plant. Here for the first time, these hairs are described using LM, SEM and TEM, and their possible functions discussed.

Key words: Epidermis, crypt, glandular hair, Maxillaria, Maxillariinae, polyphenols, resin, trichome

\section{INTRODUCTION}

Extra-floral, resin-secreting, glandular hairs have long been known to occur in Orchidaceae. Almost a century and a half has passed since Möbius (1887) first described reduced, glandular hairs in Maxillaria Ruiz \& Pav. Since then, similar sunken hairs have been described for many other orchid genera, including Bulbophyllum Thouars, Epidendrum L., Stanhopea Frost ex Hook. and Dendrobium Sw., as well as Pleurothallidinae (S olereder and Me yer, 1930; Pridgeon, 1982; Stern and Morris, 1992; Morris, Stern and Judd, 1996). In each case, these bicellular trichomes cover small areas of the leaf surface. However, reports do not always agree on the number of cells that constitute these trichomes. In fact, the hairs are multicellular in juvenile leaves, but at maturity, the trichome apex becomes broken off or is dissolved (Holtzmeier, Stern and Judd, 1998). Furthermore, Solereder and Meyer (1930) reported and figured unsunken "hair bodies" comprising four mucilage-secreting, stalked cells on the adaxial leaf surface of Maxillaria picta Hook. (now Brasil- iorchis picta (Hook.) R. S inger, S. K o e h le r \& Carnevali). Holtzmeier et al. (1998), however, on examining that same species, failed to find them.

The distribution of foliar, resin-secreting, bicellular, glandular hairs in caespitose Maxillaria species assigned to Senghas's Group XI (cushion plants; Senghas, 1993, 1994) is variable. Holt z m e ie r et al. (1998) have reported that they occur both adaxially and abaxially in most species [and are particularly numerous on the abaxial leaf surfaces of $M$. aff. callichroma Rchb.f. and M. cucullata Lindl. (Camaridium cucullatum (Lindl.) M.A. Blanco)], but are confined to the adaxial leaf surface of $M$. porphyrostele Rchb.f. (Brasiliorchis porphyrostele (Rchb.f.) R. Singer, S. Koehler \& Carnevali), and are completely absent from the leaves of M. picta. Although the pseudobulbs of these last two species were reported to be glabrous, those of all other Maxillaria spp. examined were reported to bear trichomes, but only sporadically. These were solitary, multicellular structures with bulbous tips and were sunken in crypts. Birefringent, anastomosing bands of thickening were present in walls of crypt cells surrounding hair bases of $M$. endresii Rchb.f. and $M$. cucullata.

Similar sunken, but often paired hairs have also been recorded from both foliar surfaces and pseudobulbs of other taxa assigned to sub-tribe Maxillariinae Benth., including Anthosiphon roseans Schltr. (Cryptocentrum roseans (Schltr.) A. D. Hawkes), Cryptocentrum gracillimum Ames \& C. Schweinf., Cyrtidiorchis frontinoensis (Garay) S. Rauschert ( S t e r n J u d d and C a r l s w a r d , 2004), Mormolyca ringens (Lindl.) Gentil and Trigonidium obtusum Lindl. (H o l t z m e i e r et al. 1998). Moreover, sunken hairs 
also occur amongst representatives of Cryptarrheninae Dressler, Zygopetalinae Schltr., Lycastinae Schltr. and Telipogoninae Schltr. Glandular, sunken hairs, however, are confined to Lycastinae (including Bifrenariinae Dressler and Xylobium Lindl.) and Maxillariinae (S tern et al., 2004).

The exudate produced by these trichomes usually contains terpenes and essential oils (Dell and McComb, 1978) and may function primarily as a repellent and deterrent to herbivory (L e v i n, 1973; $\mathrm{W}$ a g n e r , 1991). Another function attributed to exudates copiously produced in some desert plants, is the increased reflection of light and resultant reduction of leaf temperature.

Although resin-secreting trichomes are fairly common on vegetative organs, they have only infrequently been recorded for flowers; mainly members of Clusiaceae (Hochwallner and W e be r, 2006), Euphorbiaceae (A mbruster and Webster, 1979) and occasionally, Orchidaceae (Singer and Koe hle r, 2004). Here, we report on the occurrence and structure of resin-secreting, floral trichomes in the Neotropical orchid, Maxillaria dichroma Rolfe.

\section{MATERIALS AND METHODS}

Flowers of Maxillaria dichroma Rolfe (Accession No. S19990297; det. E. A. Ch ris te n s o n, 2009) were obtained from Swansea Botanical Complex, Swansea, UK and voucher material deposited at the herbarium of the National Museum of Wales, Cardiff, UK (NMW V.1999.042.005).

The position of resin-secreting trichomes in intact flowers was determined using an Olympus SZX12 stereo-microscope and Nikon Optiphot II fluorescence microscope. Hand-cut sections through tepals were tested for starch and lipids using IKI and a saturated alcoholic solution of Sudan III, respectively. The tissue was also stained with ruthenium red to test for the presence of pectin and mucilage, and with alcoholic phloroglucinol + concentrated hydrochloric acid for lignin. Fluorescence microscopy using UV light was used to detect polyphenols (V a u g h n, 1987; R o s h in a, 2003).

Samples of tepal tissue were fixed in $2.5 \%$ glutaraldehyde / $5 \%$ sucrose in phosphate buffer $(0.075 \mathrm{M}$; ph 6.8) for $4 \mathrm{~h}$ at $20^{\circ} \mathrm{C}$, washed in phosphate buffer and post-fixed in $1 \%$ osmium tetroxide at $0^{\circ} \mathrm{C}$ for $2 \mathrm{~h}$. The fixed material was then dehydrated using a graded ethanol series, infiltrated and embedded in Spurr resin. For general histology, semi-thin sections (approx 1 $\mu \mathrm{m}$ thick) were stained using $1 \%(\mathrm{w} / \mathrm{v})$ toluidine blue $\mathrm{O}(\mathrm{TBO})$ in $1 \%(\mathrm{w} / \mathrm{v})$ aqueous sodium tetraborate solution (O' B rien, Feder and M c Cully, 1964; $\mathrm{V}$ a u g h n , 1987) and examined using light microsco- py (LM). Micrometry and photomicrography of hairs were accomplished using a Nikon Eclipse 600 microscope with Screen Measurement version 4.21 software. For transmission electron microscopy (TEM), sections were cut at approx $60 \mathrm{~nm}$ thickness using a glass knife and a Reichert Ultracut-S microtome. Sections were stained with uranyl acetate and lead citrate and examined using a TESLA BS 340 transmission electron microscope. Fixed pieces of tissue were also dehydrated in acetone, subjected to critical-point drying using liquid $\mathrm{CO}_{2}$, sputter-coated with gold and examined by means of a TESLA BS-300 scanning electron microscope (SEM).

\section{RESULTS}

Floral, resin-secreting trichomes are located upon both surfaces of all tepals of Maxillaria dichro$m a$, including the labellum. The adaxial surface of the latter has a prominent callus, whose cells contain dark polyphenols. Sunken trichomes are sparsely distributed abaxially upon the tepals (Fig. 1) at a mean density of 2.5 per $\mathrm{mm}^{2}$ epidermal surface, whereas the adaxial surface bears trichomes only sporadically (Fig. 2). Stomata also occur on both epidermal surfaces, intermingled with secretory hairs.

The bicellular, epidermal trichomes comprise a basal cell and a glandular, apical cell (Figs 3-8, 10, 14). The former is sunken into an epidermal crypt, whereas the latter is exserted (Figs 3-5, 8, 10, 14). The basal cell is smaller than adjacent epidermal cells and contains darkly-staining, granular cytoplasm (Figs 4-5, 7 ) that is more opaque than that of underlying parenchyma (Figs 6-8). Testing with IKI did not indicate the presence of starch in trichomes, nor other epidermal cells, but did reveal the presence of prominent, intravacuolar protein bodies in adaxial epidermal cells and underlying parenchyma (Fig. 9). The cuticle and cell wall, but not the secreted material, stained with Sudan III (Fig. 6) and large accumulations of lipid droplets were observed in bundle sheaths.

The apical cell is oval to ellipsoid with mean dimensions of $34.0 \mu \mathrm{m} \times 18.85 \mu \mathrm{m}$ (Figs 3-8, 11-12, 14). Its wall is greatly $\mathrm{C}$-thickened on the cuticle side (Figs $3-5,14)$ and both cuticle and wall stain blue-green with TBO, indicating the presence of polyphenols (Figs 45 ). Fluorescence of the apical cell wall and secretion, when exposed to UV light, confirmed the presence of polyphenols (Fig. 3), whereas treatment with acidified phloroglucinol failed to reveal the presence of lignin in cell walls. Neither cuticular layer, nor secreted material, stained with ruthenium red (Fig. 10). The cuticle is reticulate and a loose arrangement of elements can be recognized towards the innermost edge (Fig. 15). Droplets of secretory material were observed at the in- 

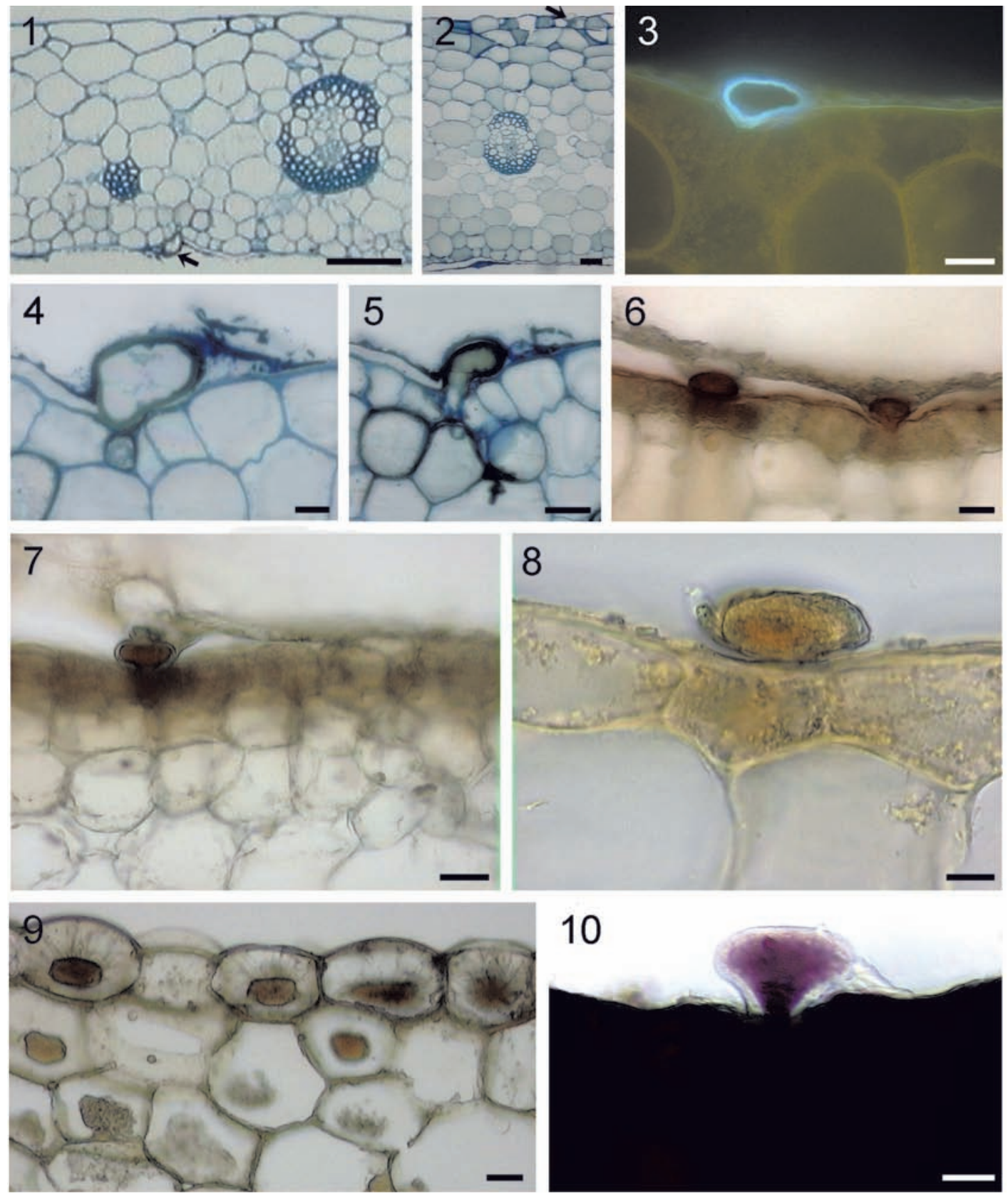

Figs 1-10. Structure and histochemistry of resin-secreting trichomes (LM).

Fig. 1. Transverse section of lateral sepal with resin-secreting trichome (arrow) located on abaxial surface.

Fig. 2. Resin-secreting trichome (arrow) on adaxial surface of lateral sepal. Secretory residues are visible on abaxial surface.

Fig. 3. Secretion and cell wall of secretory trichome showing blue autofluorescence under UV light.

Fig. 4. Secretory trichome composed of basal cell and apical cell; the cell wall stained blue-green with TBO indicating presence of polyphenols.

Fig. 5. Secretion, both inside and outside apical cell, stained dark blue-green with TBO indicating polyphenolic composition.

Fig. 6. Secretory trichomes stained with Sudan III. The cuticle covering the apical cell and tepal epidermis, as well as cell walls, are stained, indicating presence of lipids, whereas the rest of the section remains unstained.

Fig. 7. Section treated with IKI. Here, cytoplasm of apical cell and basal cell of trichome, as well as that of epidermal cells, stains intensely. However, the secretion remains unstained and there is no evidence that the secretory hair contains starch.

Fig. 8. Protoplasts of secretory trichome and tepal epidermis stain more intensely with IKI than those of underlying parenchyma.

Fig. 9. IKI also stains protein bodies in adaxial epidermal cells and some parenchyma cells. Fig. 10. Section treated with ruthenium red showing that only a very narrow region of the secretory trichome wall contains pectin (stained red), whereas the wider, outer cuticular layer and the secretion remain unstained.

Scale bars $=50 \mu \mathrm{m}$ (Fig. 1) and $20 \mu \mathrm{m}$ (Figs 2-10). 

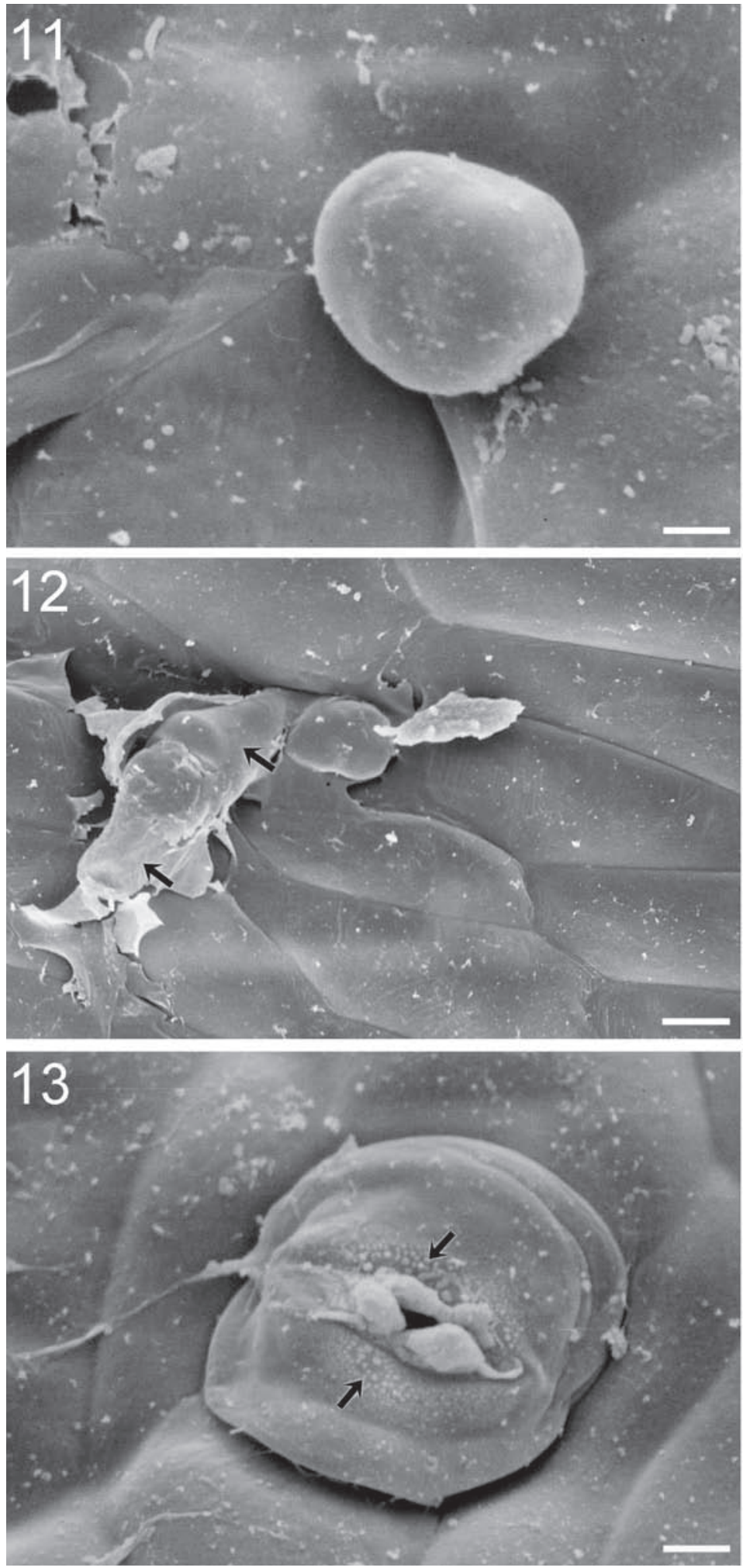

Figs 11-13. Abaxial epidermis of tepal (SEM).

Fig. 11. Almost spherical, apical cell of secretory hair with no visible pores in the overlying cuticle. Fig. 12. Secretory residues upon the secretory hair and surface of adjacent epidermal cells (arrows). Fig. 13. Stoma bearing lipid droplets (arrows). Such droplets occur only infrequently on stomata. Scale bars $=8.5 \mu \mathrm{m}$ (Fig. 11.), $22 \mu \mathrm{m}$ (Fig. 12.) and $5.5 \mu \mathrm{m}$ (Fig. 13.), respectively. 

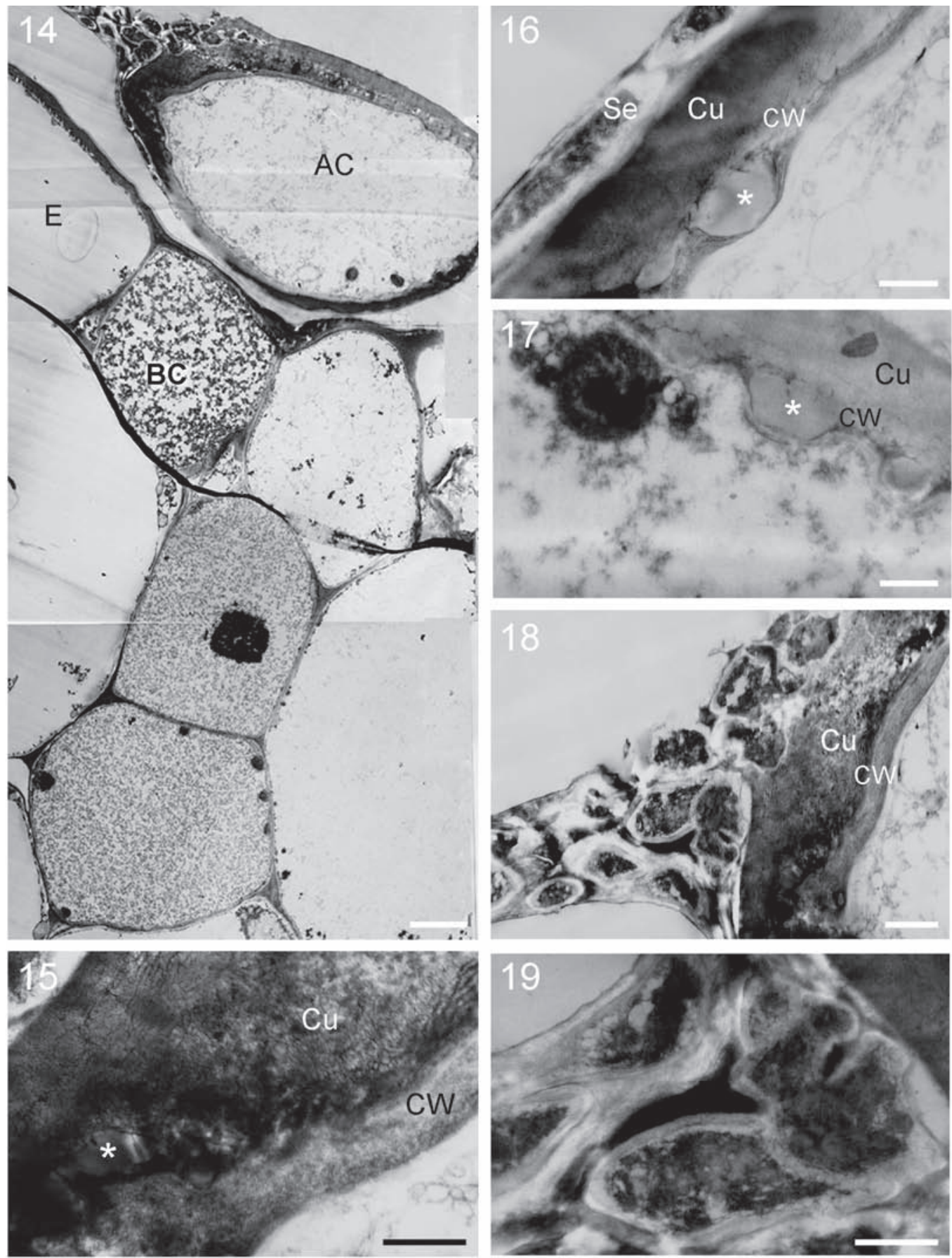

Figs 14-19. Ultrastructure of resin-secreting trichome (TEM).

Fig. 14. Photographic reconstruction of whole trichome. Note apical cell with granular secretion upon its surface and flocculent precipitates in the basal cell and underlying parenchyma cells.

Fig. 15. Cell wall of apical cell with associated cuticle. The innermost region of the latter is reticulate, whereas the outer is lamellate. Between the cell wall and cuticle occur droplets of secretion (asterisk).

Fig. 16. Secretion (asterisk) occurs between cell wall and cuticular layer. It also occurs in granular form on the surface of apical cell.

Fig. 17. Cytoplasm with remains of organelles and secretion (asterisk). The latter is found in the periplasmic space and also at the interface between the cell wall and cuticular layer.

Fig. 18. Secretory granules on surface of apical cell.

Fig. 19. Detail of secretion showing electron-dense contents surrounded by an electron-translucent sheath. Scale bars $=4.5 \mu \mathrm{m}$ (Fig. 14.), $0.5 \mu \mathrm{m}$ (Fig. 15.), $0.5 \mu \mathrm{m}$ (Figs 16, 17.), $1.0 \mu \mathrm{m}$ (Fig. 18.) and $0.5 \mu \mathrm{m}$ (Fig. 19), respectively. 

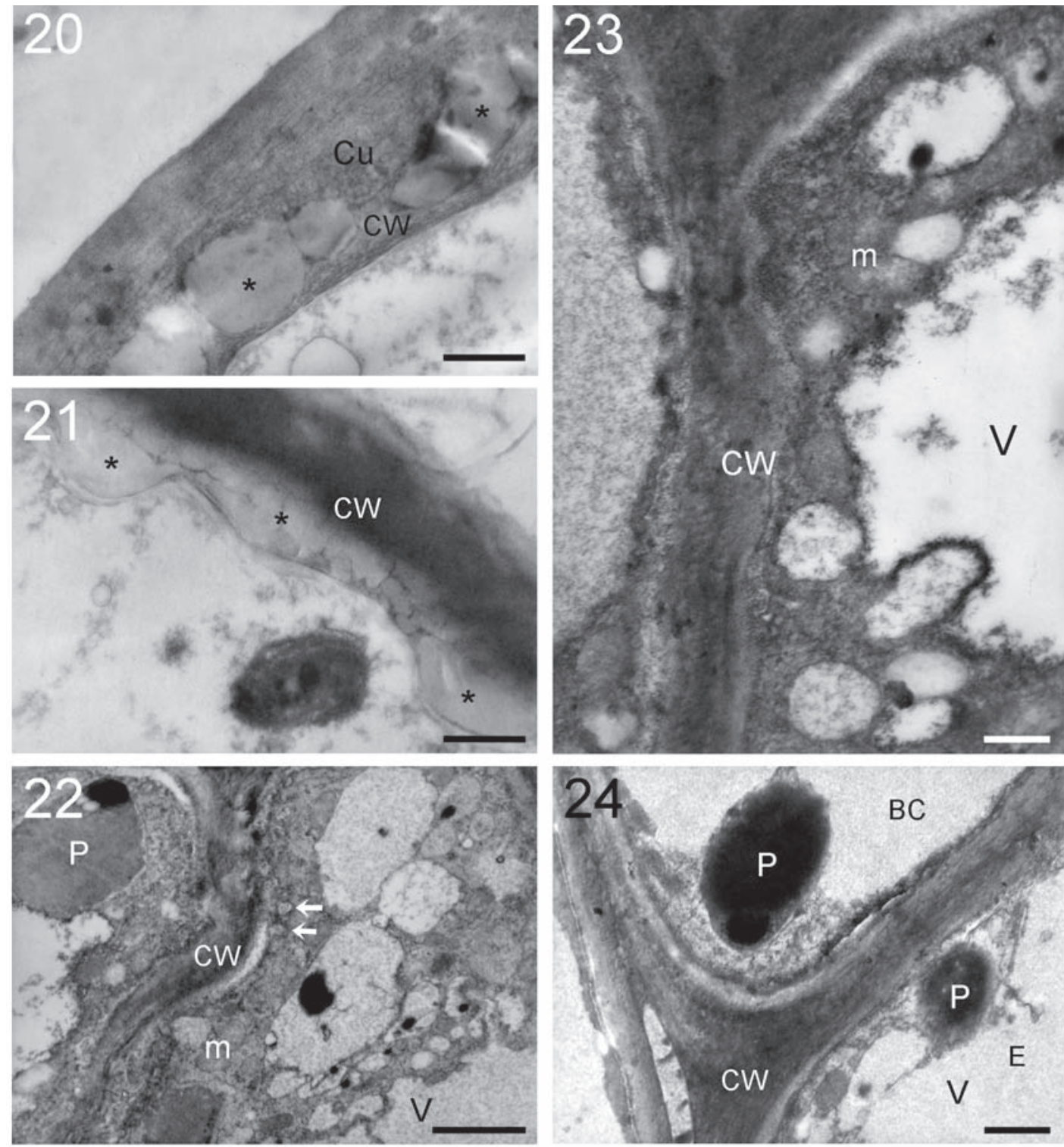

Figs 20-24. Ultrastructure of resin-secreting trichome and epidermal cells (TEM).

Fig. 20. Secretion (asterisk) at interface between cell wall and cuticular layer. Note electron-translucent cytoplasm.

Fig. 21. Inner tangential wall of apical cell (adjacent to basal cell) with secretion (asterisk) visible in periplasmic space. The plastid envelope is disrupted.

Fig. 22. Basal cell and adjacent epidermal cell. The darkly stained, granular cytoplasm contains plastids and mitochondria, whereas the vacuole of the basal cell contains osmiophilic precipitates. Arrows indicate secretory vesicles near cell wall.

Fig. 23. Cell wall and parietal cytoplasm of basal and epidermal cell. Vacuole contains dark precipitates that are also visible along the tonoplast and within small enclaves of the large, central vacuole.

Fig. 24. Electron-translucent cytoplasm of basal and epidermal cells, whose plastids have an osmiophilic stroma.

Scale bars $=0.5 \mu \mathrm{m}$ (Figs 20, 21), $1.0 \mu \mathrm{m}$ (Fig. 22), $0.5 \mu \mathrm{m}$ (Figs 23, 24), respectively.

Key to figures

$\mathrm{AC}=$ apical cell

$\mathrm{BC}=$ basal cell

$\mathrm{Cu}=$ cuticle

$\mathrm{CW}=$ cell wall

$\mathrm{E}=$ epidermis

$\mathrm{m}=$ mitochondrion

$\mathrm{P}=$ plastid

$\mathrm{Se}=$ secretion

$\mathrm{V}=$ vacuole 
terface between cell wall and cuticle, and these were also present both in the periplasmic space and the cell wall itself (Figs 15-17, 20-21). Secreted material occurred in close proximity to glandular hairs (Figs 3-7, 12, 14), but not usually stomata (Fig. 13). The secretion, as observed using TEM, has a granular appearance, and these granules are surrounded by an electron-translucent sheath (Figs 18-19). Granules were predominantly associated with the trichome apex, but were also observed, on occasion, some distance from the latter as a thin film covering areas of the epidermis.

The cytoplasm of the apical cell is electrontranslucent and contains membrane profiles, vesicles and the remains of plastids (Figs 14, 16-18, 20, 21). The large, central vacuole contains dark, polyphenolic precipitates (Fig. 14). Conversely, the cytoplasm of the basal cell is much more electron-opaque and contains numerous mitochondria and starchless leucoplasts, each plastid containing osmiophilic globules and relatively few membranes embedded in a darkly stained stroma (Figs 22-24). Profiles of smooth endoplasmic reticulum (SER) and vesicles were seen near the plasmalemma. Dark, flocculent precipitates are present in the central vacuole, as well as in the vacuoles of adjacent epidermal and parenchyma cells (Figs 14, 22, 23). Smaller vacuoles with dark precipitates also occur in the parietal cytoplasm (Figs 22, 23).

\section{DISCUSSION}

The floral trichomes of $M$. dichroma are identical to those described for vegetative organs of other Maxillariinae and Lycastinae in that they are sunken and bicellular, comprising a basal cell, which is not exserted, and an apical glandular cell that secretes resin. Furthermore, they are sparsely distributed on both adaxial and abaxial tepal surfaces.

Trichome cell walls and cuticle contain polyphenols and lipoidal compounds. The latter were seemingly absent from secreted material, which also failed to stain with ruthenium red, indicating that it is not mucilaginous, as proposed by some authors. The trichome cells have an organelle complement typical of secretory cells, and the abundance of SER and intravacuolar polyphenols is indicative of cells involved in lipid metabolism.

It has been suggested that resin-secreting hairs may deter herbivory and indeed, it has been shown that other polyphenolic compounds, such as tannins, are able to precipitate salivary proteins (Fe e ny, 1976; S w a i n , 1979; H a s l a m, 1981). Nevertheless, their precise role remains conjectural ( $\mathrm{S} h$ a $\mathrm{r} \mathrm{m}$ a and $\mathrm{V}$ a $\mathrm{n}$ g a n i, 1987). Muller (1969), for example, argued that such compounds are waste products or "accidents of metabolism" and are sequestered in harmless form within mature tissues or ephemeral organs, such as leaves. The toxins are then dissipated following abscission. Another possibility is that polyphenolic compounds can inhibit growth induced by gibberellins and may be implicated in growth regulation ( $\mathrm{C}$ or c o r a n, Ge is s m an and Ph in ney, 1972; C or c or an and $\mathrm{G} r$ e e $n, 1975)$. However, some of these explanations, at least in this case, are problematical. For example, the proposal that the presence of resin-secreting hairs alone discourages herbivory seems näive in that leaves of many Maxillaria spp. are coriaceous, have a thick cuticle, well developed hypodermal sclerenchyma, islands of sclerenchyma scattered throughout the photosynthetic mesophyll and sclerotic bundle caps. They also contain tannins, idioblasts with stegmata (silica bodies) and raphides (Holtzmeier et al. 1998; D a vies 1999; S te r $n$ et al. 2004). In Maxillaria, resin-secreting hairs are very sparsely distributed and at best would contribute only marginally to such an arsenal of herbivore-deterring characters. Likewise, it is unlikely that so few hairs could make a significant difference to the regulation of excretory products, especially when there is evidence that large quantities of polyphenols are sequestered in vacuoles elsewhere in the plant body. It is, however, possible that these hairs may, to a limited degree, reflect light and thereby prevent leaf scorch, especially in immature leaves. The possibility that viscous resin secretions may physically impede insect movement also poses problems. The flowers of $M$. dichroma, like many members of the $M$. grandiflora (Kunth) Lindl. alliance, are relatively large (4 cm from tip to tip of lateral sepals), mainly white with pale yellow farina on the mid-lobe of the labellum and marked with red. They are highly fragrant. Furthermore, like certain other Maxillaria spp., they produce floral-food rewards in the form of proteinrich pseudopollen (D a vies and W inters, 1998; Davies, Winters and Turner, 2000, Davies, Turner and Gregg, 2003a; Davies and Turner, 2004; M a tu si ew i cz, S t p i c z yńs ka and D a vies, 2004; D avies and S t piczyńs ka, 2008; D a vie s, 2009) and this is thought to be gathered by stingless bees (Meliponini). As such, the flowers are susceptible to damage by insects and molluscs. The presence of secretion could perhaps physically impede insect movement, or noxious chemicals present in the secretion could perhaps discourage herbivory or irritate molluscs. However, since the secretion, once exuded, remains close to the trichome, this is unlikely. Besides, some species of the former Maxillaria (now assigned to Rhetinantha M.A. Blanco and Heterotaxis Lindl.) produce floral resin as a food-reward for pollinating insects (Davies, Turner and Gregg, 2003a, b; Davies and Turner, 2004; Flach et al., 2004; Davies and Stpiczyńska, 2008; 
Davies, 2009), although this, unlike that produced by resin-secreting hairs, stains intensely with Sudan III (Davies et al., 2003a, b; Davies and Turner, 2004).

In attributing a function to these hairs, perhaps the best clue is that in juvenile leaves, they are multicellular (H o l t z m e i e r et al., 1998). It is thus speculated that prior to expansion of the lamina, they would be more densely distributed upon the leaf surface affording the young organ a degree of pubescence. This in turn, would perhaps reduce transpiration and protect the young leaf from desiccation. Furthermore, before the cuticle is fully developed, secreted resin would render the juvenile leaf surface waterproof. Therefore, regardless of whether they occur on leaf or floral bud, it is quite possible that the main role of these hairs is the protection of developing organs. This, perhaps, also explains why such trichomes occur predominantly upon the abaxial surface of tepals. On maturation of the organ, the hairs perhaps become redundant, or at least have limited function. How the chemical composition of their secretion differs from the resinous food-reward produced by the labella of certain Maxillaria spp. has yet to be investigated fully.

\section{Acknowledgments}

The authors would like to thank mgr Agata Pacek (University of Life Sciences, Lublin) and Alan Gregg (Swansea Botanical Complex, UK) for help in preparing figures and manuscript, respectively, as well as Dr. Joanna Strubińska (University of Maria CurieSkłodowska, Lublin) for use of fluorescence microscopy facilities.

\section{REFERENCES}

Ambruster W. S., Webster G. L., 1979. Pollination of two species of Dalechampia (Euphorbiaceae) in Mexico by euglossine bees. Biotropica, 11: 278-283.

Corcoran M. R., Geissman T. A., Phinney B. O., 1972. Tannins as gibberellin antagonists. Plant Physiol. 47: 323-330.

Corcoran M. R., Green F. B., 1975. Inhibitory action of five tannins on growth induced by several gibberellins. Plant Physiol. 56: 801-806.

Davies K. L., 1999. A preliminary survey of foliar anatomy in Maxillaria. Lindleyana, 14: 126-135.

Davies K. L., 2009. Food-hair form and diversification in orchids. [In:] X, Kull T., J. Arditti, and S. M. Wong (eds), Orchid Biology-Reviews and Perspectives: 159184, Springer.

Davies K. L., Stpiczyńska M., 2008. The anatomical basis of floral, food-reward production in Orchidaceae. [In:] J. A. Teixeira da Silva (ed.), Floriculture, Ornamental and Plant Biotechnology, V: 392-407. Global Science Books, UK.
Davies K. L., Turner M. P., 2004. Morphology of floral papillae in Maxillaria Ruiz \& Pav. (Orchidaceae). Ann. Bot. 93: 75-86.

Davies K. L., Turner M. P., Gregg A., 2003a. Atypical pseudopollen-forming hairs in Maxillaria Ruiz \& Pav. (Orchidaceae). Bot. J. Linn. Soc. 143:151-158.

Davies K. L., Turner M. P., Gregg A., 2003b. Lipoidal labellar secretions in Maxillaria Ruiz \& Pav. (Orchidaceae). Ann. Bot. 91: 439-446.

Davies K. L., Winters C., 1998. Ultrastructure of the labellar epidermis in selected Maxillaria species (Orchidaceae). Bot. J. Linn. Soc. 126: 349-361.

Davies K. L., Winters C., Turner M. P., 2000. Pseudopollen: its structure and development in Maxillaria (Orchidaceae). Ann. Bot. 85: 887-895.

De11 B., McComb J. A., 1978. Plant resins - their formation, secretion and possible functions. Adv. Bot. Res. 6: 276-316.

Feeny P,. 1976. Plant apparency and chemical defense. Recent. Adv. Phytochem. 10: 1-40.

Flach A., Dondon R. C., Singer R. B., Koehler S., A maral M. C. E., Mars aioli A. J., 2004. The chemistry of pollination in selected Brazilian Maxillariinae orchids: Floral rewards and fragrance. J. Chem. Ecol. 30: 1045-1056.

H a s l a m E., 1981. Vegetable tannins. [In:] E. E. Conn (ed.), The biochemistry of plants - a comprehensive treatise, 7: 527-556, Academic Press, New York.

Hochwallner H., Weber A,. 2006. Flower development and anatomy of Clusia valerioi, a Central American species of Clusiaceae offering floral resin. Flora - Morphology, Distribution, Functional Ecology of Plants 201 (5): 407-418.

Holtz meier M. A., S ter n W. L., Ju d d W. S., 1998. Comparative anatomy and systematics of Senghas's cushion species of Maxillaria (Orchidaceae). Bot. J. Linn. Soc. 127: 43-82.

Lev in D. A., 1973. The role of trichomes in plant defence. Q. Rev. Biol. 48: 3-15.

Matusiewicz J., Stpiczyńska M., Davies K. L., 2004. Pseudopollen in the flowers of Maxillaria lepidota Lindl. (Orchidaceae). Proceedings of the 53rd Meeting of the Polish Botanical Society, Toruń: 14.

Möbiu s M., 1887. Über den anatomischen Bau der Orchideenblätter und dessen Bedeutung für das System dieser Famalie. Jahrbücher für Wissenschaffliche Botanik. 18: 530-607.

Morris M. W., Stern W. L., Judd W. S., 1996. Vegetative anatomy and systematics of subtribe Dendrobiinae (Orchidaceae). Bot. J. Linn. Soc. 120: 89-144.

Mulle r C. H., 1969. The 'co' in coevolution. Science 164: 197.

O'Brien T. P., Feder N., McCully M. E., 1964. Polychromatic staining of plant cell walls by toluidine blue O. Protoplasma, 59: 367-373.

Pridgeon A. M., 1982. Diagnostic anatomical characters in the Pleurothallidinae (Orchidaceae). Am. J. Bot. 69: 921-938. 
Roshin a V., 2003. Autofluorescence of plant secreting cells as a biosensor and bioindicator reaction. J. Fluorescence 13: 403-418.

Senghas K., 1993. Subtribus Maxillariinae. [In:] F. G. Breiger, R. Maatsch, K. Senghas, R. Schlechter (eds), Die Orchideen, 28: 1713-1776, Blackwell Wissenschafts-Verlag, Berlin.

Senghas K., 1994. Subtribus Maxillariinae. [In:] Die Orchideen 28, Breiger, F. G., Maatsch R., Senghas K., Rudolph Schlechter (eds): 1777-1840. Blackwell Wissenschafts-Verlag, Berlin.

Sharma B. D., Vangani P., 1987. Anatomy of Psilotum nudum - a reassessment. Bionature 7: 5-9.

Singer R., Ko eh ler S., 2004. Pollinarium morphology and floral rewards in Brazilian Maxillariinae (Orchidaceae). Ann. Bot. 93: 39-51.

Solereder H., Meyer F. J., 1930. Systematic anatomy of the monocotyledons VI: Microspermae. Golek B. (ed.). Translated from the German Systematische Anatomie der Monocotyledonen VI: Microspermae, by Herzberg A., 1969). Washington, D. C: Israel Program for Scientific Translations, Smithsonian Institution.

Stern W. L., Judd W. S., Carlsward B. S., 2004. Systematic and comparative anatomy of Maxillariaeae (Orchidaceae), sans Oncidiinae. Bot. J. Linn. Soc. 144: 251-274.

Stern W. L., Morris M. W., 1992. Vegetative anatomy of Stanhopea (Orchidaceae) with special reference to pseudobulb water-storage cells. Lindleyana 7: 34-53
Swa in T., 1979. Tannins and lignins. [In:] G. A. Rosenthal and D. H. Janzen (eds), Herbivores; their interactions with secondary plant metabolites: 3-19. Academic Press, London.

Va u g h K. C., 1987. CRC handbook of plant cytochemistry. CRC Press Inc. Boca Raton, Florida.

Wagner G. J., 1991. Secreting glandular trichomes: more than just hairs. Plant Physiol. 96: 675-679.

\section{Włoski żywiczne w kwiatach Maxillaria dichroma Rolfe (Orchidaceae: Maxillariinae)}

\section{Streszczenie}

Włoski gruczołowe wydzielające żywice występują na wegetatywnych organach u roślin z rodzaju Maxillaria oraz u pokrewnych taksonów. Dotychczas nie stwierdzono występowania zagłębionych włosków żywicznych w kwiatach Maxillaria, nie są znane również szczegóły budowy tego rodzaju włosków. W niniejszej pracy udokumentowano po raz pierwszy ich budowę na poziomie mikroskopu świetlnego oraz elektronowego skaningowego i transmisyjnego, a także dyskutowane są ich funkcje. 
